\title{
From University to Multiversity to \\ Omniversity: HEIs as Hubs for Dynamic Development
}

\author{
Roberta Malee Bassett
}

Omni: in all ways or places; Omniverse: a universe that is spacio-temporally fourdimensional (Merriam-Webster).

When Clark Kerr coined the term 'multiversity', in 1963, he provided a dynamic proposition for the expanded purpose and value of higher education institutions (HEIs): "New knowledge is the most important factor in economic and social growth... What the railroads did for the second half of the last (19th) century, and the automobile for the first half of this (20th) century, may be done for the second half of this century by the knowledge industry: that is, to serve as the focal point for national growth." Kerr (1963) foretold the knowledge economy to come-that the real growth in economic development would not come through manufacturing or expanded industrialization, but instead from knowledge and information-and argued that universities would be the engines of that growth: the 'multiversity,' serving as a centre for teaching and learning, of course, but also for research and engagement beyond the classroom.

While utilizing James (1895) work on the multiverse, Kerr (1963) compared the multiversity to the university as like a federal republic versus a kingdom, where attention is paid to each part as separate and integrated versus seeing the entirety as all forms merged into one. Yet, this federated institution was still based on an identity tied specifically to location, mission, and the historic population of that campus (staff and students). An institution in three dimensions: teaching, research, and engagement with the community.

It is here where the omniversity diverges from its academic forebearers.

With its four-dimensional dynamic, the 21 st Century omniversity is a multiversity without borders or limits to its academic mission, taking the convening power of the university truly global. Creating hubs for teaching, research, innovation,

R. M. Bassett (凶)

The World Bank, Washington, DC, USA

e-mail: rbassett@worldbank.org 
entrepreneurship, and more than those previously anchored in local, regional, and national communities to create a span of impact and influence across the entire globe. The omniversity is a place where location - the institutions', students', and academic staff's-is almost irrelevant. Core functions are delivered in blended formats, engaging an institutional community not bound together via the physical plant of a campus but by a shared institutional mission. The omniversity is and will be one major piece in the dynamic puzzle that is the future of higher education.

First, then, is to define an omniversity and the emergence of such an institution from its origins of the university and multiversity. Since an exhaustive google search did not result in any previous use of the term, this is an opportunity to identify and define the omniversity as a major, transformational higher education institution of the present and future. In this rethinking of the constituent parts of a university, the omniversity is an institution that not only capitalizes on the concentration of talent, resources, reputation, and reach under its unified organizational umbrella to drive knowledge creation and dissemination as a broad-scale global enterprise, it also has the capacity and agility to innovate and expand its sphere of influence. The omniversity is a transcendent enterprise of global education reach and impact. As the definition of omni above attests - an omniversity is a university that is "in all ways or places." Indeed, such institutions most definitely exist today and are destined to expand in number and impact to drive global higher education in the future.

In looking at how an HEI would be "in all ways and places," we can first think about the "ways." The traditional universities first delivered teaching on a campus and encouraged its faculty to conduct research. The multiversity sought to expand the influence of the knowledge exchanged and developed on campus to external social and economic development but did not require broadscale definitional change to the modes of doing business. Teaching and research remained the anchors of multiversity engagements. What changed in the evolution of traditional universities to multiversities (again, as defined by Kerr and subsequent scholars of higher education) was an expanded notion of why HEIs operated as they did and the expected impacts of the enterprise-HEIs were widely accepted as social and economic engines. With the omniversity, social and economic development as an outcome of traditional teaching and research is far too limited.

Next, how the evolution of university-multiversity-omniversity was possible is very much a story of technology and globalization. The addition of this fourth, borderless, dimension to the core functions of the university, transforming the university to a onmiversity, was only possible with the massive growth in information and communication technology (ICT), the ease and affordability of international travel, and the global expansion of the knowledge economy. A HEI need not be local to deliver its curriculum to students, given the near ubiquity of ICT for education. Academic staff and students could (and will one day again) get on a plane and relocate for their work anywhere in the world. Government, industry, students, and staff all have grown to understand that the best outcomes from education are now in a knowledge-driven, global economy and society. All of this relies on advanced, borderless, high quality education-the omniversity. 
How does the omniversity differ from the university and multiversity in practical terms? Here are some emergent characteristics that pull the university of the past into the omniversity of the present and future:

- For students

- Multiple pathways to desired outcomes

- Traditional 3-4 year courses for a first degree

- Short course options (micro-credentials) to seek specific skill development of knowledge

- Stacked micro-credentials (from one or more HEIs) to achieve degrees

- Multiple modes of learning

- Traditional, campus-based instruction

- Blended learning, with time on and away from one or more physical campuses

- Fully remote participation, from anywhere, asynchronously.

- For academic staff

- Multiple career pathways

- Teaching only, with expertise especially in the pedagogy of remote learning, in multiple formats - in person, asynchronous online, short courses for skill development, traditional courses relying on longer-term relationship building, etc.

- Teaching and research, following a traditional model and with support from the teaching-specific staff

- Research only, building and innovating mechanisms for blended and remote research opportunities, to promote borderless communities of knowledge production and application

- For administrative staff

- Expanded role of ICT specialists into the core functions of the institution

- Expanded need for extra-academic support for its borderless and unbounded student populations, based in centres that span global time zones, for constant availability, with skills including:

- academic support staff and coaches with skills in global languages

- knowledge of student development theory (for traditional and non-traditional students)

- learning science expertise, to support academic staff and students in course development and delivery

- Expanded knowledge of quality assurance-both in support of crafting high quality, agile academic programs and in ensuring cross border programs achieve credential and degree recognition status in the countries where students are based 
- Expanded role of staff in building relationships with external stakeholders, including employers, investors, entrepreneurs, policymakers, and community leaders, to ensure relevance and adaptability of the education to the outcome potential of students and research.

Some of these are familiar today. Some are anathema to how universities operate in their national, traditional contexts. But, all of these are and will be core functions of the omniversity, which does, in fact, exist in some nascent form already.

Where are the omniversities of today? They are not yet the drivers of global higher education nor the beacons that attract policymakers, investors, academic staff, and students. They are, instead, making those institutions that dominate the global rankings and have captured the imagination of all those who aspire to world-class university status very nervous. Perhaps they will result from global mergers, where a central institution purchases, partners, or somehow pulls an array of institutions outside its existing borders under its own organizational umbrella. Institutions will perhaps choose to unite within a consortium, with some autonomy but shared delivery and global reach. Or, perhaps a strong leader emerges with a vision for a coalition of programs and staff unbound by location or tradition under this new HEI and has the charisma and influence to make it happen.

An institution that comes closest to this broad-scale definition of the omniversity is Arizona State University (USA), which has created an entire complementary institution to its traditional base to deliver global remote learning options on every continent while remaining anchored to its campus in Tempe, Arizona. Even ASU remains largely bound to its geographic location and language of instruction. Innovators in East Asia and the Middle East continue to seek avenues to push the boundaries of what higher education can be and whom it can serve. With the necessary resources, talent, and imagination, these education leaders may be the hubs of new, boundless, global omniversities.

It sounds almost like science-fiction that an institution can be a kind of education empire. It might also be seen as driving a form of education colonialism if unchecked and unfettered. If we learn anything from the changes being wrought by the COVID19 pandemic, we should learn this - the inevitable globalization of higher education will not necessarily come in one form, and higher education must continue to evolve to be more useful, adaptive, accessible, and meaningful. If the omniversity emerges that provides education to a borderless community of students and scholars in formats that span from the most applied short course to the most advanced doctoral program, with multiple modes of delivery and engagement and agile pathways for student achievement and research excellence, then the evolution of higher education in the 21 st century can surely be considered a success with obvious and unassailable relevance. For personal, social, and economic development, the omniversity can be an engine of transformative and sustainable good. 


\section{References}

James, W. (1895), "Is Life Worth Living?", Int. J. Ethics, 6(1), 1-24.

Kerr, C. (1963). The Uses of the University. Harvard University Press.

Roberta Malee Bassett is Global Lead for Tertiary Education and Senior Education Specialist at the World Bank, providing leadership and technical expertise for projects related to postsecondary education reform initiatives around the world. She currently serves on the Editorial Board of Higher Education Quarterly and the International Advisory Board of the International Network for Higher Education in Africa (INHEA) and teaches at the Harvard Graduate School of Education.

Open Access This chapter is licensed under the terms of the Creative Commons Attribution 4.0 International License (http://creativecommons.org/licenses/by/4.0/), which permits use, sharing, adaptation, distribution and reproduction in any medium or format, as long as you give appropriate credit to the original author(s) and the source, provide a link to the Creative Commons license and indicate if changes were made.

The images or other third party material in this chapter are included in the chapter's Creative Commons license, unless indicated otherwise in a credit line to the material. If material is not included in the chapter's Creative Commons license and your intended use is not permitted by statutory regulation or exceeds the permitted use, you will need to obtain permission directly from the copyright holder. 